\title{
Cytotoxic Fatty Acid from Pleurocybella porrigens
}

\author{
Tatsuya Hasegana, Mayumi Ishibashi, Takanobu Takata, Fumihide Takano, and Tomihisa OhtA* \\ Department of Pharmacognosy and Chemistry of Natural Products, Graduate School of Natural Science and Technology, \\ Kanazawa University; Kakuma-machi, Kanazawa 920-1192, Japan. \\ Received July 3, 2007; accepted September 11, 2007
}

\begin{abstract}
The new conjugated ketonic fatty acid, porrigenic acid (1), was isolated as a cytotoxic constituent of Pleurocybella porrigens. The structure of 1 was elucidated using spectroscopic methods including 1D and 2D NMR and MS. The absolute stereochemistry of 1 was determined by application of the exciton chirality method. Compound 1 exhibited cytotoxic activity against myeloma THP-1 cells, but did not show any significant toxicity against B16F1 melanoma. This is the first report of the isolation and structural elucidation of the new cytotoxic constituent porrigenic acid (1) from the edible mushroom $P$. porrigens.
\end{abstract}

Key words Pleurocybella porrigens; Tricholomataceae; conjugated ketonic fatty acid; porrigenic acid; exciton chirality method; cytotoxic activity

The fungus Pleurocybella porrigens (called 'sugihiratake' in Japanese), which is a basidiomycete of the Trichoromataceae family, is a lignicolous agaric mushroom that produces pure white, relatively small pleurotoid fruiting bodies on rotting conifers, often in abundance. ${ }^{1)}$ This edible mushroom grows during the late summer and autumn and is native to all districts of Japan, including the Tohoku and Hokuriku areas. P. porrigens was suspected to cause acute encephalopathy including coma and spasm in the Tohoku and Hokuriku areas in $2004 .^{2-4)}$ We have recently reported that an intraperitoneal administration of a hot water extract of $P$. porrigens caused acute toxic death with hemorrhagic anemia in mice within $24 \mathrm{~h}$, and the toxicant was in part a thermolabile high molecule contained in this mushroom. ${ }^{5)}$ However, the toxic constituents responsible for patients with critical encephalopathy and nephrosis have not yet been clarified. In this study, we therefore isolated the toxic constituents from $P$. porrigens, and report here the isolation and structural elucidation of a new ketonic fatty acid conjugated with porrigenic acid (1) and its cytotoxic activity.

\section{Results and Discussion}

The $\mathrm{MeOH}$ extract of $P$. porrigens $(2.5 \mathrm{~kg}$ fresh weight $)$ was partitioned between EtOAc and $\mathrm{H}_{2} \mathrm{O}$, and the EtOAc layer was subjected to bioassay-guided fractionation with repeated flash column chromatography on silica gel and ODS and further purified by HPLC equipped with an ODS column to afford new compound $\mathbf{1}$.

Compound $\mathbf{1}$ was obtained as a colorless solid, and its molecular formula, $\mathrm{C}_{18} \mathrm{H}_{30} \mathrm{O}_{4}$, was established from HR-FABMS, which gave a pseudomolecular ion peak at $\mathrm{m} / \mathrm{z} 311.2214$ $[\mathrm{M}+\mathrm{H}]^{+}$. The ${ }^{13} \mathrm{C}-\mathrm{NMR}$, DEPT, and HMQC spectra (Table 1) of 1 showed signals of one methyl, 10 methylenes, five methines, and two quaternary carbons including a carboxylic acid ( $\delta 177.9, \mathrm{C}-1)$ and a ketone $(\delta 203.7, \mathrm{C}-9)$, respectively. The presence of two conjugated $E, E$-form enone systems was revealed by the ${ }^{1} \mathrm{H}-\mathrm{NMR}$ spectrum (Table 1$)$ of $\mathbf{1}[\delta 6.20$ $(1 \mathrm{H}, \mathrm{d}, J=15.6 \mathrm{~Hz}, \mathrm{H}-10), \delta 6.23(1 \mathrm{H}, \mathrm{dd}, J=5.4,15.1 \mathrm{~Hz}$, $\mathrm{H}-13), \delta 6.40(1 \mathrm{H}, \mathrm{dd}, J=11.7,15.1 \mathrm{~Hz}, \mathrm{H}-12), \delta 7.26(1 \mathrm{H}$, dd, $J=11.7,15.6 \mathrm{~Hz}, \mathrm{H}-11)]$. Furthermore, the UV spectrum of 1 displayed a $\lambda_{\max }$ at $\left.273 \mathrm{~nm} .{ }^{6}\right)$ The ${ }^{1} \mathrm{H}-\mathrm{NMR}$ spectrum (Table 1) showed signals at $0.92(3 \mathrm{H}), 1.33(10 \mathrm{H})$, and 1.59 (6H) ppm, which can be attributed to the terminal methyl to methylene groups of aliphatic chains. HMBC correlations were observed at $\mathrm{H}-2 / \mathrm{C}-1, \mathrm{C}-3, \mathrm{C}-4$; H-8/C-6, C-7, C-9, C10; H-10/C-9; H-11/C-9; H-17/C-15, C-16, C-18; and H18/C-16, C-17. Further analysis of EI-MS data indicated that notable fragment ion peaks were observed at $\mathrm{m} / \mathrm{z} 57,87,139$, and 167. The locations of a carbonyl carbon $(\delta 203.7)$ at C-9 and an oxygenated methine carbon $(\delta 72.6)$ at $\mathrm{C}-14$ were identified from the HMBC spectrum and EI-MS analysis (Fig. 2). Based on the above data, compound 1 was determined to be $(10 E, 12 E)$-14-hydroxy-9-oxo-10,12-octadecadienoic acid. A racemic mixture of $\mathbf{1}$ was isolated from the same mushroom by Amakura et al. ${ }^{7)}$ When the optical rotation $[\alpha]_{\mathrm{D}}^{28}-10.5^{\circ}(c=0.088, \mathrm{MeOH})$ was measured for compound $\mathbf{1}$, it was not due to a racemic compound. Therefore

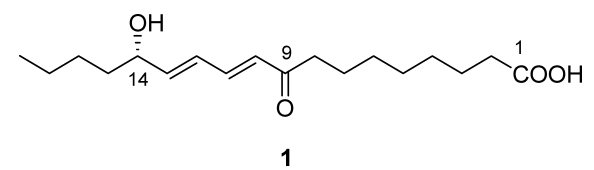

Fig. 1. Structure of Compound (1) Isolated from P. porrigens

Table 1. ${ }^{13} \mathrm{C}$ - and ${ }^{1} \mathrm{H}-\mathrm{NMR}$ Spectral Data for $\mathbf{1}^{a)}$ in $\mathrm{CD}_{3} \mathrm{OD}$

\begin{tabular}{rrl}
\hline \hline & \multicolumn{2}{c}{ Porrigenic acid $(\mathbf{1})$} \\
\cline { 2 - 3 } Position & $\delta_{\mathrm{C}}$ & \multicolumn{1}{c}{$\delta_{\mathrm{H}}$} \\
\hline 1 & 177.9 & $2.27(2 \mathrm{H}, \mathrm{t}, 7.3)$ \\
2 & 38.0 & $1.59(2 \mathrm{H}, \mathrm{brs})$ \\
3 & 27.7 & $1.33(2 \mathrm{H}, \mathrm{brs})$ \\
4 & 30.1 & $1.33(2 \mathrm{H}, \mathrm{brs})$ \\
5 & 30.1 & $1.33(2 \mathrm{H}, \mathrm{brs})$ \\
6 & 30.2 & $1.59(2 \mathrm{H}, \mathrm{brs})$ \\
7 & 25.5 & $2.61(2 \mathrm{H}, \mathrm{t}, 7.3)$ \\
8 & 41.1 & $6.20(1 \mathrm{H}, \mathrm{d}, 15.6)$ \\
9 & 203.7 & $7.26(1 \mathrm{H}, \mathrm{dd}, 11.7,15.6)$ \\
10 & 130.3 & $6.40(1 \mathrm{H}, \mathrm{dd}, 11.7,15.1)$ \\
11 & 144.3 & $6.23(1 \mathrm{H}, \mathrm{dd}, 5.4,15.1)$ \\
12 & 128.8 & $4.17(1 \mathrm{H}, \mathrm{m})$ \\
13 & 148.5 & $1.59(2 \mathrm{H}, \mathrm{brs})$ \\
14 & 72.6 & $1.33(2 \mathrm{H}, \mathrm{brs})$ \\
15 & 37.8 & $1.33(2 \mathrm{H}, \mathrm{brs})$ \\
16 & 28.7 & $0.92(3 \mathrm{H}, \mathrm{t}, 6.8)$ \\
17 & 23.7 & \\
18 & 14.4 & \\
& & \\
\hline & &
\end{tabular}

a) Values in parentheses indicate coupling constants in $\mathrm{Hz}$. 


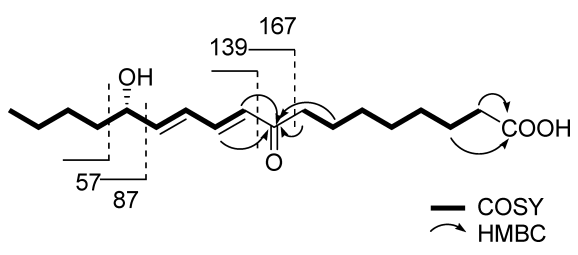

Fig. 2. HMBC Key Correlations of Compound (1) and EI-MS Analysis of Compound (1)

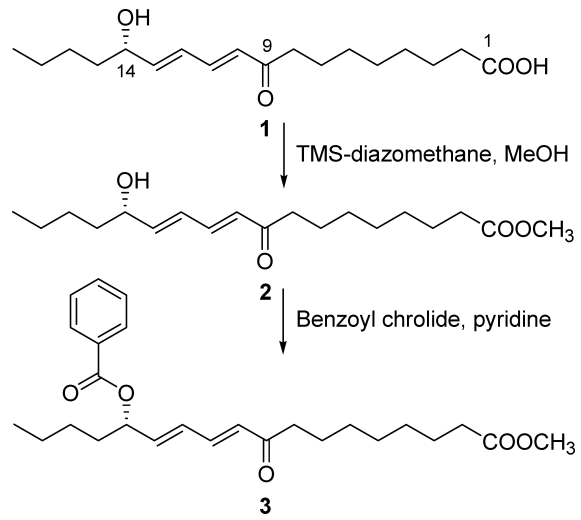

Chart 1. Synthesis of Compound (3)

the absolute stereochemistry of C-14 was determined using the $\mathrm{CD}$ allylic benzoate method. ${ }^{8}$ The carboxylic acid moiety of 1 was esterified with TMS-diazomethane in $\mathrm{MeOH}$, and then the hydroxyl groups (C-14) were esterified with benzoyl chloride in dry pyridine to obtain compound 3 (see Chart 1). The CD spectrum of 3 exhibited a negative benzoate Cotton effect at $230 \mathrm{~nm}$. Therefore the absolute stereochemistry of C-14 was assigned to have the $S$ configuration. Thus compound 1 was determined to be $(S)-(10 E, 12 E)-14-$ hydroxy-9-oxo-10,12-octadecadienoic acid, a new conjugated ketonic fatty acid called porrigenic acid (Fig. 1).

Conjugated ketonic fatty acids have been found in natural plants $^{6}$ and mushrooms, ${ }^{7}$ although the biological activity of the fatty acid was unclear. Kawagishi et al., ${ }^{9)}$ showed that some conjugated ketonic fatty acid analogues have relatively potent inhibitory activity against aldehyde dehydrogenase in cell-free conditions. We therefore tried to assess the cytotoxic activity of compound $\mathbf{1}$ in both cultured human myeloma THP-1 cells and murine melanoma B16F1 cells. Compound 1 exhibited cytotoxicity against cultured THP-1 cells with an $\mathrm{IC}_{50}$ value of $46.5 \mu \mathrm{g} / \mathrm{ml}$, while no cytotoxic activity was observed when murine B16F1 cells were cultured with various concentrations $(0.8-50 \mu \mathrm{g} / \mathrm{ml})$ of compound $\mathbf{1}$. This suggests that compound $\mathbf{1}$ has lineage-specific cell cytotoxicity. To the best of our knowledge, this is the first report of the isolation and structural elucidation of the new cytotoxic constituent porrigenic acid (1) from the edible mushroom $P$. porrigens.

\section{Experimental}

General Optical rotations were determined with a Horiba SEPA-3000 high-sensitive polarimeter. UV spectra were measured on a Shimadzu UV1600 UV-visible spectrometer. CD spectra were recorded on a JASCO J-820 spectrometer. NMR spectra were recorded on a JEOL GSX-500 spectrometer in $\mathrm{CD}_{3} \mathrm{OD}$ and $\mathrm{CDCl}_{3}$. Chemical shifts were referenced to the residual solvent peaks $\mathrm{CD}_{3} \mathrm{OD}\left(\delta_{\mathrm{H}} 3.30\right.$ and $\left.\delta_{\mathrm{C}} 49.8\right)$ and $\mathrm{CDCl}_{3}\left(\delta_{\mathrm{H}} 7.26\right.$ and $\delta_{\mathrm{C}}$ 77.0). Mass spectra were measured on a JEOL SX-102 mass spectrometer. Reverse-phase HPLC was performed on SunFire Prep $C_{18}(5 \mu \mathrm{m}$; $10 \times 250 \mathrm{~mm}$; Waters). Silica gel $(63-210 \mu \mathrm{m}$, Kanto Chemical Co.) and
ODS (63-212 $\mu \mathrm{m}$, Wako) and were used for flash column chromatography TLC was performed on silica gel $60 \mathrm{~F}_{254}$ (Merck) and RP-18 $\mathrm{F}_{254 \mathrm{~S}}$ (Merck).

Material P. porrigens was taxonomically identified and collected in Yamagata prefecture during the fall of 2006 and deposited in a database at Kanazawa University Graduate School of Science and Technology under registration number T2006. Raw mushroom samples were quickly frozen at $-80^{\circ} \mathrm{C}$ until use.

Extraction and Isolation The fruiting bodies of $P$. porrigens $(2.5 \mathrm{~kg}$ wet weight) were extracted three times with $\mathrm{MeOH}$ at room temperature, and the combined extracts were concentrated and partitioned between water and EtOAc. The EtOAc layer was separated by silica gel flash column chromatography with gradient mixtures of $n$-hexane, EtOAc, and $\mathrm{MeOH}$ to give 10 fractions. A biological fraction was further separated by silica gel flash column chromatography with a stepwise gradient of $\mathrm{CHCl}_{3}$ and $\mathrm{MeOH}$, and ODS flash column chromatography with a stepwise gradient of aqueous $\mathrm{MeOH}$. A biological fraction was purified by ODS HPLC with $75 \% \mathrm{MeOH}$ and $50 \% \mathrm{CH}_{3} \mathrm{CN}$ to give compound $1(2.2 \mathrm{mg})$

Porrigenic Acid (1): Colorless solid. $[\alpha]_{\mathrm{D}}^{28}-10.5^{\circ}(c=0.088, \mathrm{MeOH})$. UV $(\mathrm{MeOH}) \lambda_{\max }(\log \varepsilon) 273(4.2) \mathrm{nm} .{ }^{1} \mathrm{H}-\mathrm{NMR}$ spectral data $(500 \mathrm{MHz}$, $\left.\mathrm{CD}_{3} \mathrm{OD}\right)$ and ${ }^{13} \mathrm{C}-\mathrm{NMR}$ spectral data $\left(125 \mathrm{MHz}, \mathrm{CD}_{3} \mathrm{OD}\right)$ are shown in Table 1. HR-FAB-MS $m / z: 311.2214[\mathrm{M}+\mathrm{H}]^{+}$(Calcd for $\mathrm{C}_{18} \mathrm{H}_{31} \mathrm{O}_{4}, 311.2222$ ).

Methyl Ester of 1 (2): To an ice-cooled solution of $1(1.0 \mathrm{mg})$ in $\mathrm{MeOH}$ $(0.5 \mathrm{ml})$ TMS-diazomethane- $\mathrm{Et}_{2} \mathrm{O}(0.5 \mathrm{ml})$ was added, and the mixture was stirred at room temperature for $2 \mathrm{~h}$. After the addition of two drops of acetic acid, the mixture evaporated to afford $2(1.0 \mathrm{mg})$ as a colorless oil. Colorless oil. $[\alpha]_{\mathrm{D}}^{28}-11.5^{\circ}(c=0.048, \mathrm{MeOH}) .{ }^{1} \mathrm{H}-\mathrm{NMR}\left(500 \mathrm{MHz}, \mathrm{CDCl}_{3}\right) \delta 0.94$ $(3 \mathrm{H}, \mathrm{t}, J=8.1 \mathrm{~Hz}, \mathrm{H}-18), 1.32(10 \mathrm{H}$, br s, H-4, 5, 6, 16, 17), $1.59(6 \mathrm{H}$, br s $\mathrm{H}-3,7,15), 2.30(2 \mathrm{H}, \mathrm{t}, J=7.3 \mathrm{~Hz}, \mathrm{H}-2), 2.60(2 \mathrm{H}, \mathrm{t}, J=7.3 \mathrm{~Hz}, \mathrm{H}-8), 3.64$ $(3 \mathrm{H}, \mathrm{s}, \mathrm{O}-\mathrm{Me}), 4.19$ (1H, m, H-14), $6.21(2 \mathrm{H}, \mathrm{m}, \mathrm{H}-10,13), 6.41(1 \mathrm{H}, \mathrm{dd}$ $J=10.7,15.1 \mathrm{~Hz}, \mathrm{H}-12), 7.26(1 \mathrm{H}, \mathrm{dd}, J=10.3,15.6 \mathrm{~Hz}, \mathrm{H}-11)$. EI-MS $m / z$ : $324[\mathrm{M}]^{+}$

Benzoyl Ester of 2 (3): To synthesize the benzoyl derivative of 2, an icecooled solution of $2(0.4 \mathrm{mg})$ in dry pyridine $(0.5 \mathrm{ml})$ was mixed with benzoyl chloride $(0.15 \mathrm{ml})$, and the mixture was stirred at room temperature for $20 \mathrm{~h}$. Two drops of $\mathrm{MeOH}$ were added to the reaction mixture, stirred for $10 \mathrm{~min}$, and then diluted with EtOAc and aqueous $\mathrm{Na}_{2} \mathrm{CO}_{3}$, and the layers were separated. The organic layer was washed with brine, and the combined aqueous layers were extracted with EtOAc. The combined organic extracts were dried over $\mathrm{MgSO}_{4}$ and concentrated. The residual dark-brown oil was purified by silica gel flash column chromatography (eluted with nhexane/EtOAc $4: 1)$ to give $3(0.3 \mathrm{mg})$ as a colorless oil. Colorless oil. [ $\alpha]_{\mathrm{D}}^{28}$ $-46.3^{\circ}(c=0.008, \mathrm{MeOH}) . \mathrm{CD}(\mathrm{MeOH}) \Delta \varepsilon_{198}+28.5, \Delta \varepsilon_{230}-9.8 .{ }^{1} \mathrm{H}-\mathrm{NMR}$ $\left(500 \mathrm{MHz}, \mathrm{CDCl}_{3}\right) \delta 0.91(3 \mathrm{H}, \mathrm{m}, \mathrm{H}-18), 1.30$ (10H, br s, H-4, 5, 6, 16, 17), $1.58(6 \mathrm{H}$, br s, H-3, 7, 15), $2.30(2 \mathrm{H}, \mathrm{m}, \mathrm{H}-2), 2.60(2 \mathrm{H}, \mathrm{m}, \mathrm{H}-8), 3.63(3 \mathrm{H}$, s, O-Me), 4.54 (1H, m, H-14), 6.28 (2H, m, H-10, 13), 6.47 (1H, m, H-12), 7.25 (1H, m, H-11), 7.49 (2H, m, Ar-H), 7.61 (1H, m, Ar-H), 8.04 (2H, m, Ar-H). EI-MS $m / z: 428\left[\mathrm{M}^{+}\right.$.

Measurement of Cytotoxicity The cytotoxicity of the test compounds was determined in the myeloma THP-1 monocyte cell line and B16F1 melanoma cells using the MTT method. Cell suspensions $(180 \mu \mathrm{l})$ were seeded in 96-well plates at densities of $1.0 \times 10^{5}$ cells per well with test compounds $(20 \mu \mathrm{l})$ added from DMSO stock solution. After $3 \mathrm{~d}$ of culture, attached cells were incubated with MTT $(10 \mu \mathrm{l}, 4 \mathrm{~h})$ and subsequently solubilized in $10 \%$ SDS- $N, N$-dimethylformaldehyde (DMF) solution $(100 \mu 1$, $10 \mathrm{~h}$ ). The absorbance was measured at $570 \mathrm{~nm}$ using a microplate reader.

\section{References}

1) Matsumoto T., Nagasawa E., Fukumasa-Nakai Y., Myroscience, 46, $370-375$ (2005).

2) Kurokawa K., Sato H., Nakajima K., Kawanami T., Kato T., Rinsho Shinkeigaku, 45, 111-116 (2005).

3) Kuwabara T., Arai A., Honma N., Nishizawa M., Rinsho Shinkeigaku, 45, 239-245 (2005).

4) Obara K., Okawa S., Kobayashi M., Takahashi S., Watanabe S., Toyoshima I., Rinsho Shinkeigaku, 45, 253-256 (2005).

5) Takano F., Yamaguchi M., Shoda S., Zi-Dong F., Ohta T., Nat. Med., 59, 151-156 (2005).

6) Hamburger M., Handa S. S., Cordell G. A., Kinghorn A. D., Farnsworth N. R., J. Nat. Prod., 50, 281-283 (1987).

7) Amakura Y., Kondo K., Akiyama H., Ito H., Hatano T., Yoshida T., Maitani T., Chem. Pharm. Bull., 54, 1213-1215 (2006).

8) Harada N., Iwabuchi J., Yokota Y., Uda H., J. Am. Chem. Soc., 103, $5590-5591$ (1981).

9) Kawagishi H., Miyazawa T., Kume H., Arimoto Y., Inakuma T., J. Nat. Prod., 65, 1712-1714 (2002) 